\title{
Selection of Coffee Shop Business Locations Using the Analytical Hierarchy Process Method
}

\author{
Ahmad Fauzi ${ }^{1}$, Novita Indriyani ${ }^{2}$, Andika Bayu Hasta Yanto ${ }^{3)}$ \\ ${ }^{1,3}$ Teknik dan Informatika, Universitas Bina Sarana Informatika, J1.Kramat Raya No.98, Senen, Jakarta Pusat \\ ${ }^{2}$ Teknik dan Informatika, Universitas Bina Sarana Informatika Kampus Kota Bogor, Komplek Pesona Intiland \\ J1. Raya Cilebut Kel. Sukaresmi Tanah Sareal - Bogor
}

\begin{tabular}{|c|c|}
\hline Article Info & ABSTRACT \\
\hline Article history: & The Coffee Shop business is one of the trending businesses in Indonesia, so \\
\hline Received 10 08, 2021 & $\begin{array}{l}\text { competition in this business field can be said to be increasing rapidly. In order } \\
\text { to get a strategic business location, the majority of decision makers are wrong }\end{array}$ \\
\hline Revised 12 10, 2021 & in choosing the location of their business, this is due to the lack of analysis and \\
\hline Accepted 12 13, 2021 & $\begin{array}{l}\text { to the data from the location survey and the lack of decision-making limitations } \\
\text { in analyzing the survey data. For this reason, it is necessary to create a system, }\end{array}$ \\
\hline Keywords: & $\begin{array}{l}\text { where this system uses the Analytical Hierarchy Process (AHP) method to } \\
\text { assist in processing survey data. The application of the Analytical Hierarchy }\end{array}$ \\
\hline Coffee & \\
\hline Analytical & is determined using 7 (criteria) criteria including rental prices, buildings, clean \\
\hline Hierarchy & $\begin{array}{l}\text { water, accessibility, distance to offices, internet connections and electricity } \\
\text { sources. The final result of the process using the AHP method is ranking of }\end{array}$ \\
\hline Process & several alternative locations that have been set, and several alternative \\
\hline Method & $\begin{array}{l}\text { locations get the highest global weight, it becomes recommendations for the } \\
\text { development of this coffee shop business. }\end{array}$ \\
\hline
\end{tabular}

This is an open access article under the CC BY-SA license.

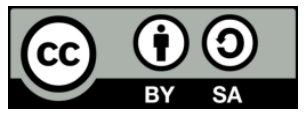

\section{Corresponding Author:}

Ahmad Fauzi

Teknik dan Informatika

Universitas Bina Sarana Informatika

(C) The Author(s) 2021

\section{Introduction}

Coffee shop is promising business in recent times. Currently, coffee is not always related to the habits of most parents, but it has become a trend of urban society when it is gathered. Competition for the coffee business is also getting strict, this can be seen in the number of coffee shops from the upper class to the lower class spread out in several areas, especially the capital city. Most people today prefer to drink coffee at coffee shop or cafe than at home. Coffee shops are chosen as trading business because it does not require large capital to start but the promised profits are quite tempting and prestigious to be the owner of coffee shop. In choosing a location to open a business, it will also have an effect on determining a promising business, researchers try to analyze and design a decision support system (DSS) where researchers use the Analytical Hierarchy Process (AHP) method. It will assist researchers in solving the problem of choosing a coffee shop on opening location with several alternative areas including Kelapa Gading, Mangga Dua, Matraman and Kemang. The results of this regional comparison will produce something to support in making decision which area is suitable for opening a coffee shop. In the technique of meeting needs, one of them is the information needs so widely, and from the information obtained when we use it as decision in determining a quality and determining a decision [1].

\section{Research Method}

In this research method, there are several relevant researchs were conducted with different locations and methods used to complete this research. 


\subsection{Analytical Hierarchy Process}

AHP method helps to solve complex problems by structuring hierarchy of criteria, stakeholders, outcomes and various considerations to develop weights or priorities. This method also combines the power of feelings and logic involved in various problems, then synthesizes various considerations into match results by estimates intuitively as presented in the considerations have been made. In its development, AHP can solve complex or unframed problems with quite a lot of aspects or criteria. This complexity is caused by the unclear problem structure, uncertainty in the perception of decision making, and uncertainty of the availability or even the absence of accurate statistical data. Sometimes there are perceived and observed decision problems to be taken as soon as possible, but the variations are complicated so that it is impossible for the data to be recorded numerically, it can be measured based on the perception of experience and intuition by using qualitative. However, it is possible that other models will participate. considered during the decision-making process with AHP approach, especially in understanding individual decision makers during the process of applying this approach[2]. The advantage of AHP method is that at the final step a consensus can be drawn which is a combination of opinions from all parties who are experts. The step in analyzing AHP data (Suryadi and Ramdhani, 2000) are stated as follows[3]:

1. Identification of the system

It is to identify problems and determine the desired solution. System identification is done by studying references and discussing with experts who understand the problem, in order to obtain relevant concepts with the problems.

2. Preparation of hierarchical structure

It begins with general objectives, then with criteria and sub-criteria. The lowest hierarchical structure contains possible strategic alternatives.

3. Assessment of criteria and alternatives

It was assessed through pairs comparisons. According to Saaty (1988), for various problems, scale of 1 to 9 is the best scale for expressing opinions. The value and definition of qualitative opinion from the Saaty comparison scale can be seen in table 1 .

Table 1. Scale of pairs comparison value

\begin{tabular}{cl}
\hline Intensity & \multicolumn{1}{c}{ Criteria } \\
\hline 1 & Both elements are same important \\
5 & One element a bit more important than others \\
7 & One element more important than others \\
9 & One element most important than others \\
$2,4,6,8$ & One element absolutly most important than others
\end{tabular}

Source: (Saaty, 2001)

In this AHP, alternative assessments can be carried out using the direct method. The method used to enter quantitative data. Usually these values come from previous analysis or from experience and detailed understanding of the decision problem. If the decision maker has experience or a great understanding of the decision problem, then it can directly enter the weight of each alternative.

4. Prioritization

For each criteria and alternative, pairs comparison are necessary. Relative comparison values are processed to determine alternative rankings from all alternatives. Both qualitative criteria, as well as quantitative criteria, can be compared according to predetermined assessment to produce weights and priorities. The weights or priorities are calculated by manipulating the matrix or by solving mathematical equations. The considerations for pairs comparison are synthesized to obtain overall priorities through the following steps:

a. Square the matrix of pairs comparison.

b. Count the number of values for each row, then normalize the matrix.

5. Logical consistency

All elements are logically grouped and ranked consistently according to logical criteria. The weight matrix obtained from the pairs comparison must have cardinal and ordinal relationship. The relationship can be shown as follows:

Cardinal relationship : aij.ajk=aik

Ordinal relationship : $A_{i}>A_{j}, A_{j}>A_{k}$, maka $A_{i}>A_{k}$

The relationship above can be seen from two things as follows: 
a. By looking at multiplicative preferences, for example, if grapes are four times tastier than mangoes and mangoes are twice tastier than bananas, then grapes are eight times tastier than bananas.

b. By looking at transitive preferences, for example, if grapes are tastier than mangoes and mangoes are tastier than bananas, so grapes are tastier than bananas.

In actual conditions there will be some deviations from the relationship, the matrix is not perfectly consistent. This happens because of inconsistencies in one's preferences.

Calculation of logical consistency is carried out by following steps:

a. Multiplying matrix with the corresponding priority

b. Adding multiplication results by row

c. The result of the sum of each row is divided by the respective priority and the total the results.

d. The result $\mathrm{c}$ divided by the number of element $\lambda$ maks

e. Consistency Index = CI / RI, where RI is random index consistency. If consistency ratio $\leq 0.1$, the results of the calculation of the data can be justified.

RI value is based on research conducted by Saaty (1993), which is shown in table 2.

Table 2. Random index Value

\begin{tabular}{ccccccccccc}
\hline $\begin{array}{c}\text { Orde } \\
\text { Matriks }\end{array}$ & 1 & 2 & 3 & 4 & 5 & 6 & 7 & 8 & 9 & 10 \\
\hline RI & 0,00 & 0,00 & 0,58 & 0,90 & 1,12 & 1,24 & 1,32 & 1,41 & 1,45 & 1,49
\end{tabular}

Source: (Saaty, 1993)

\subsection{Relevant Research}

Based on research in journal entitled "Selection of Initial Business Locations for Micro, Small and Medium Enterprises Using the Analytical Hierarchy Process Method" concluded that: business people need to see and consider what criteria can support the business. There are criteria used to be used as business land such as the location must be clearly visible, the location is in a crowded place, the location must have easy access, the location is close to the target market and pay attention to competitors in that location[4].

Based on research in journal entitled "Decision Support System for Choosing a Business Location for Establishing a Computer Store With Ahp Method" concludes that: To easy determine match location criteria desired by entrepreneurs. It takes a decision support system application program by using computer system to assist in making decisions quickly, precisely and accurately. It called decision support system for determining the location of computer shop with Analytical Hierarchy Process (AHP) method [5].

Based on research in the journal entitled "Design of a Decision Support System for Selection of Outstanding Students Using AHP and Promethee Method" concluded that: the results of the study indicate that with this built decision support system, the student department can choose students who are sent to an event more quickly, precise, and objective [6].

Based on research in journal entitled "Decision Support Systems for Housing Site Selection Using the Analytical Hierarchy Process (AHP)" concludes that: In this selection process several criteria are used to determine which housing location will be selected for residence and investment. This SPK assists company leaders in deciding which housing to choose [7].

Based on research in journal entitled "Decision Support System for Selection of Laptops for Operational Needs Using Ahp Method (Case Study: Directorate of Course Development and Training of the Ministry of Education and Culture" concluded that: The method used in making decisions on the selection of this laptop is the Analytical Hierarchy Process (AHP). Its because AHP method is able to break down a complex, unstructured situation into its component parts, organize parts or variables in hierarchical arrangement, assign numerical value to subjective judgments about the relative importance of each variable, and synthesize these various considerations to determine which variable has the highest priority and acts to influence situation [8].

Based on research in journal entitled "Analysis of Selection of Practical Courses Using AHP Method" concluded that: study programs in using schedules and choice of priority practical courses. This research is continuation of factor analysis in selection of practical courses where the Information Systems study program uses the Analytical Hierarchy Process (AHP) method. From the results of the analysis, it is obtained that the priority selection of practical courses from several alternatives can be useful for study programs based on criteria priority factors [9].

Based on research in journal entitled "Decision Support System for Selection of Outstanding Lecturers Using the Analytical Hierarchy Process (Ahp) Method" concluded that: The decision support system for selecting outstanding lecturers uses the Analytical Hierarchy Process (AHP) method which is carried out by 
creating paired matrix values for each criteria. The value of the paired matrix of the results must be consistent. Lecturer assessment data will be calculated with the value of paired matrix and the results of the calculation will appear in the form of rating value. The lecturer with the highest score rating deserve become the best at the Islamic University of Balitar[10].

Based on research in journal entitled "Decision Support System for Selection of Healthy Toddlers Using Ahp and Topsis Method" concluded that: Testing the decision support system for selecting healthy toddlers produces an accuracy of $50 \%[11]$.

Based on research in journal entitled "Supporting Systems in Prioritizing Selection of Promotional Media Printing Using AHP Method" concludes that: Decisions can be made based on the results of respondent stimuli by giving questionnaire containing comparisons between criteria and alternatives. And by using Expert Choice tools in data processing with AHP method. The result of testing AHP value on the frontlite base is 0.9976. And printing 1 got the first rank[12].

B Based on research in journal entitled "Decision Support System With AHP And SAW Methods On Used Car at Nava Sukses Motor" concluded that: With a Decision Support System to choose used car using Analytical Hierarchy Process (AHP) and Simple Additive Weighting (SAW) methods in determining used cars the accuracy rate reaches $73 \%$ compared to using Simple Additive Weighting (SAW) method which has accuracy rate of $60 \%$ only [13].

Based on research in journal entitled "Selection of Multi-Criteria Department Store Suppliers Using Fuzzy AHP and Topsis Method" concluded that: In this study, supplier selection was carried out by applying Multiple Criteria Decision Making (MCDM) using Fuzzy AHP and TOPSIS methods. Fuzzy AHP method can minimize uncertainty that can occur in decision making. TOPSIS by comparing the distance of the ideal negative and positive solutions [14].

Based on research in journal entitled "Evaluation of the Selection of Courier Service Providers Based on Analytical Hierarchy Process (AHP) Method" concluded that: By using AHP method, the problem of selecting spare parts suppliers will be very helpful for companies in terms of selecting the best supplier based on certain criteria.[15].

Based on research in journal entitled "Evaluation of Courier Service Provider Selection Based on Analytical Hierarchy Process (AHP) Method" concluded that: To assist decision making in the selection of logistics service providers/courier services, the authors conducted research on evaluating the selection of courier service providers, using AHP method. AHP method was chosen because this method can create an effective decision-making framework on complex problem by simplifying the decision-making process and solving the problem into criteria and then arranging the criteria in a hierarchical arrangement. So that the results of the analysis can synthesize various considerations to determine which variables have the highest priority and act to influence the results in that situation [16].

\section{Result and Discussion} follows:

In the early step of weighting with expert choice, its by entering criteria, and alternatives as

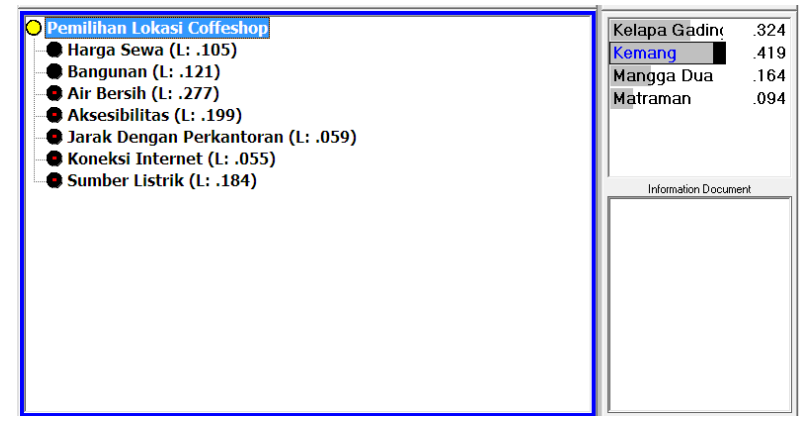

Figure 1. Criteria dan Alternative

The analysis of combined opinion of respondents that has been processed, it produces the following basic criteria: 
Priorities with respect to: Pemilihan Lokasi Coffeshop

Harga Sewa
Bangunan
Air Bersih
Aksesibilitas
Jarak Dengan Perkantoran
Koneksi Internet
Sumber Listrik
$\quad$ Inconsistency $=0.06$
with 0 missing judgments.

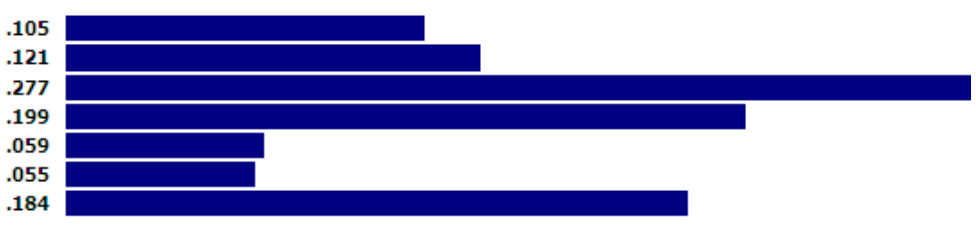

Figure 2. Basic of Criteria Value

The basic of the criteria produces an alternative selection with the following:

1. Rental Price

Priorities with respect to: Pemilihan Lokasi Coffeshop

$>$ Harga Sewa

Kelapa Gading
Kemang
Mangga Dua
Matraman
Inconsistency $=0.06$
with 0 missing judgments.

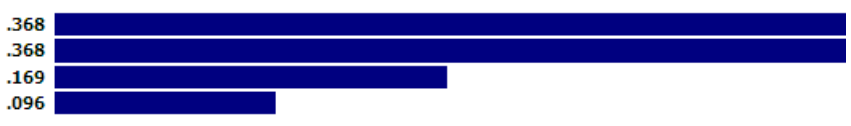

Figure 3. Basic of Alternative Value Based on Rental Price Criteria

2. Building

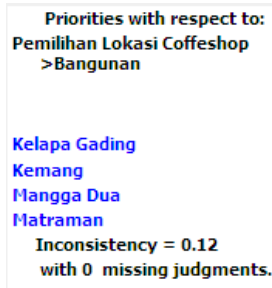

Priorities with respect to: Pemilihan Lokasi Coffeshop $>$ Bangunan

Kelapa Gading

Kemang

Mangga Dua

Matraman

Inconsistency $=0.12$

with 0 missing judgments.

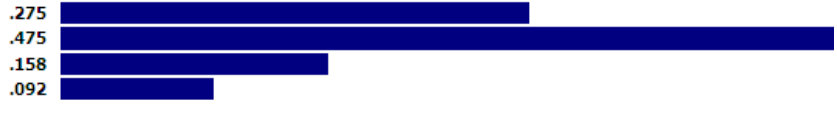

Figure 4. Basic of Alternative Value Based on Building Criteria

3. Clean Water

Priorities with respect to: Pemilihan Lokasi Coffeshop $>$ Air Bersih

Kelapa Gading Kemang

Mangga Dua

Matraman

sistency $=0.07$

with 0 missing judgment.

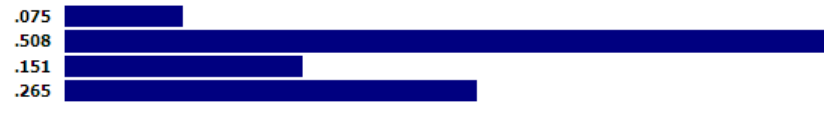

Figure 5. Basic of Alternative Value Based on Clean Water Criteria

4. Accessibility 
Priorities with respect to:

Pemilihan Lokasi Coffeshop

$>$ Aksesibilitas

Kelapa Gading

Kemang

Mangga Dua

Matraman

Inconsistency $=0.06$

with 0 missing judgments.

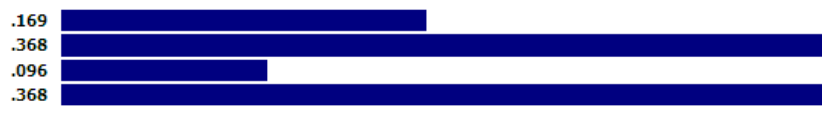

Figure 6. Basic of Alternative Value Based on Accessibilty Criteria

5. Office Distance

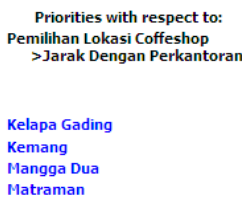

.394

Figure 7. Basic of Alternative Value Based on Office Distance

6. Internet Connection

Priorities with respect to:

Pemilihan Lokasi Coffeshop

$>$ Koneksi Internet

Kelapa Gading

Kemang

Mangga Dua

Matraman

Inconsistency $=0.09$

with 0 missing judgments.

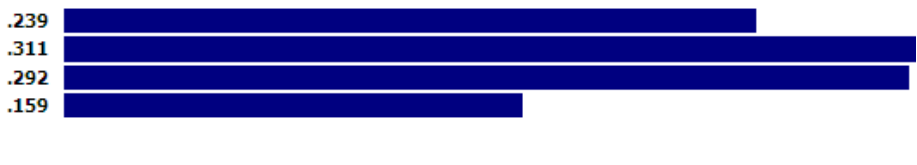

Figure 8. Basic of Alternative Value Based on Internet Connection Criteria

7. Electrical source
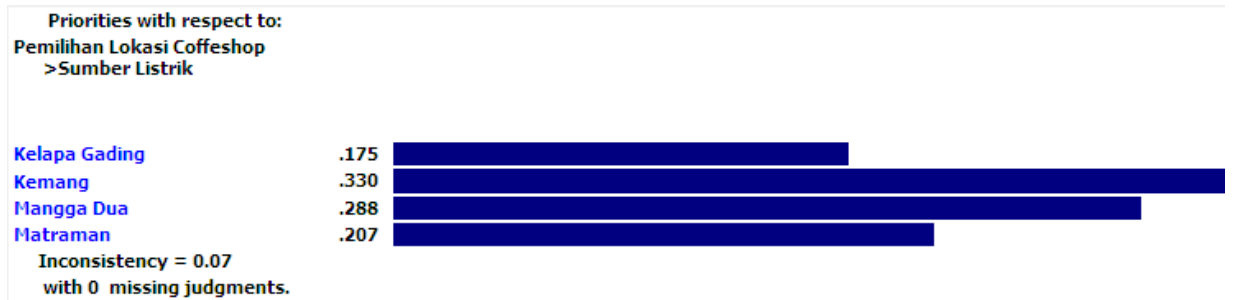

Figure 9. Basic of Alternative Value Based on Electrical Criteria obtained:

Based on the data of pairs comparison of criteria and alternatives, the following results are

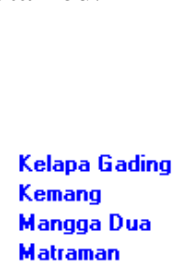

\section{Synthesis with respect to:}

Pemilihan Lokasi Coffeshop

Overall Inconsistency $=.07$

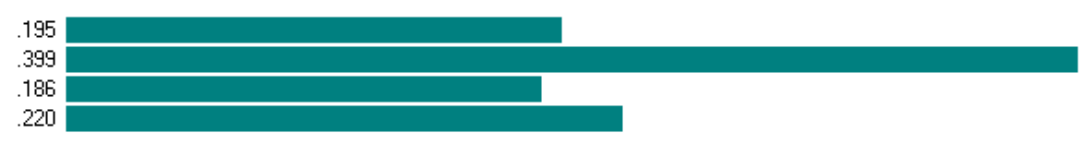

Figure 10. Synthesis Expert Choice Result

From the figure above, it can be seen that Kemang location has the highest weight, which is 0.399 so that Kemang is the best location to open a new coffeeshop business. 
The overall consistency result shows value of 0.07 so that research on the selection of coffeeshop business locations can be said to be consistent because $\mathrm{CR}<0.1$.

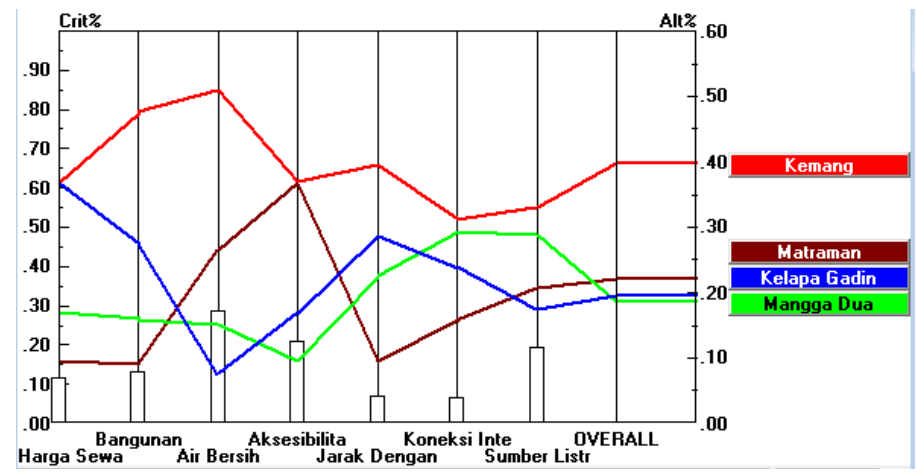

Figure 11. Performance Sensitivity Expert Choice Result

\section{Conclusion}

The conclusions of this research are: In the weighting of calculations between the criteria, it produces the highest weight is the clean water criteria with weight of 0.277 , the next criteria is accessibility with weight of 0.199 . Then, the criteria for electrical source with weight of 0.184 , the next is the criteria for building with weight of 0.121 , then the rental price with weight of 0.105 , next criteria of office distance of 0.059 and finally internet connection with weight of 0.055 .

The results of the weighting with expert choice obtained the location of Kemang with the highest weight of 0.399 , then the location of Matraman with weight of 0.220 , then the location of Kelapa Gading with weight of 0.195 , and finally the location of Mangga Dua with weight of 0.186 .

\section{References}

[1] M. H. Siregar, "Data Mining Klasterisasi Penjualan Alat-Alat Bangunan Menggunakan Metode K-Means (Studi Kasus Di Toko Adi Bangunan),” J. Teknol. Dan Open Source, vol. 1, no. 2, pp. 83-91, 2018, doi: 10.36378/jtos.v1i2.24.

[2] J. T. Informatika et al., "Sistem Pendukung Keputusan Pengangkatan Karyawan Tetap Menggunakan Metode Analytic Hierachy Process," vol. 6, no. 1.

[3] A. Fauzi and T. Hidayatulloh, "Penilaian Kinerja Karyawan Pada PT. Telecom Visitama Menggunakan Metode Analytical Hierarchy Process," Indones. J. Comput. Inf. Technol., vol. 2, no. 2, pp. 65-71, 2017.

[4] I. B. Komang Krizena Adhiarta, W. Witanti, and P. Nurul Sabrina, "Pemilihan Lokasi Awal Usaha Bagi Usaha Mikro Kecil Dan Menengah Dengan Metode Analitycal Hierarchy Process," J. Inf. Technol., vol. 3, no. 2, pp. 43-46, 2021, doi: 10.47292/joint.v3i2.63.

[5] I. Syafii, D. A. Diartono, P. Studi, T. Informatika, F. T. Informasi, and U. Stikubank, "Sistem pendukung keputusan pemilihan tempat lokasi usaha pendirian toko komputer dengan metode ahp," no. 1988, pp. 180-184, 2010.

[6] M. N. A. Julianto Lemantara, Noor Akhmad Setiawan, "Rancang Bangun Sistem Pendukung Keputusan Pemilihan Mahasiswa Berprestasi Menggunakan Metode AHP dan Promethee,” Jnteti, vol. 2, no. 4, pp. 20-28, 2013.

[7] Y. Siagian, "Sistem Pendukung Keputusan Untuk Pemilihan Perumahan Terbaik Di Asahan Menggunakan Analytical Hierarchy Pr Ocess (Ahp)," J. Teknol. Inf., vol. 1, no. 1, p. 80, 2017, doi: 10.36294/jurti.v1i1.107.

[8] G. P. Sanyoto, R. I. Handayani, and E. Widanengsih, "Sistem Pendukung Keputusan Pemilihan Laptop Untuk Kebutuhan Operasional Dengan Metode AHP (Studi Kasus: Direktorat Pembinaan Kursus Dan Pelatihan Kemdikbud)," J. Pilar Nusa Mandiri, vol. 13, no. 2, pp. 167-174, 2017.

[9] Z. Azhar, "Analisis Pemilihan Mata Kuliah Praktek Menggunakan Metode AHP," Pros. Semin. Nas. Ris. Inf. Sci., vol. 1, no. September, p. 1131, 2019, doi: 10.30645/senaris.v1i0.126.

[10] W. D. Puspitasari and D. K. Ilmi, "Sistem Pendukung Keputusan Pemilihan Dosen Berprestasi Menggunakan Metode Analytical Hierarchy Process (Ahp)," ANTIVIRUS J. Ilm. Tek. Inform., vol. 10, no. 2, pp. 56-68, 2016, doi: 10.30957/antivirus.v10i2.163.

[11] I. Zakiyah, G. Abdillah, and A. Komarudin, "Sistem Pendukung Keputusan Pemilihan Balita Sehat Menggunakan Metode AHP dan TOPSIS,”Semin. Nas. Teknol. Inf. dan Komun., vol., no., pp. 121-129, 2019.

[12] Ariani, "Sistem Penunjang Dalam Penentuan Prioritas Pemilihan Percetakan Media Promosi Menggunakan Metode AHP," J. Inform., vol. 4, no. 2, pp. 214-221, 2017.

[13] I. Setiadi, "Sistem Pendukung Keputusan Pemilihan Mobil Bekas," J. String, vol. 3, no. 3, pp. 247-257, 2019.

[14] C. O. Doaly, P. Moengin, and G. Chandiawan, "Pemilihan Multi-Kriteria Pemasok Department Store Menggunakan Metode Fuzzy Ahp Dan Topsis," J. Ilm. Tek. Ind., vol. 7, no. 1, pp. 70-78, 2019, doi: 10.24912/jitiuntar.v7i1.5037. 
[15] S. Pebakirang, A. Sutrisno, and J. Neyland, "Penerapan Metode Ahp ( Analytical Hierarchy Process ) Untuk Pemilihan Supplier Suku Cadang Di," J. Online Poros Tek. Mesin, vol. 6, no. 1, pp. 32-44, 2017.

[16] J. Astuti and E. Fatma, "Evaluasi Pemilihan Penyedia Jasa Kurir Berdasarkan Metode Analytical Hierarchy Process (Ahp)," J. Manaj. Ind. Dan Logistik, vol. 1, no. 1, p. 28, 2017, doi: 10.30988/jmil.v1i1.5. 